\title{
Contribution of Asian Industries to Hazardous Substances Management and E-waste Recycling
}

\author{
Mizue Kama ${ }^{\mathrm{a}}$, and Toshikazu Shiratori ${ }^{\mathrm{b}}$ \\ Graduated School of Environmental Studies Tohoku University, Sendai, Miyagi, 9808579, Japan \\ E-mail: amizue.kama.t6@dc.tohoku.ac.jp (Corresponding author), bshiratori@mail.kankyo.tohoku.ac.jp
}

\begin{abstract}
The purpose of E-Waste recycling is resource recovery and hazardous substances management (HSM). However, academic literature that deals with the various social aspects of HSM is limited. As such, this paper focuses on the changes for labeling method, particularly those related to hazardous substance management, and discusses how and why the current mandatory methods have been adopted. We organized the historical information related to hazardous substance management among Asian manufactures prior to the introduction of EU's RoHS Directive. In the EU, the RoHS Directive has been adopted in conjunction with the E-Waste recycling system. Initially, fulfillment of RoHS Directive requirements was confirmed through the probe assay of individual parts/products. However, Asian countries such as Japan, China and Thailand subsequently introduced product certification schemes that shared similarities with the CE mark, which had been developed as a necessary element of general supply chain management. These Asian certification schemes have played a leading role in RoHS Directive management in global manufacturing, a fact confirmed by the addition of RoHS2.0 to the EU's CE mark requirements. Thus, it can be said that HSM in Asia has contributed to the establishment of a global standard in terms of entrance control. It is important to consider the future institutional recycling design in Asian region.
\end{abstract}

Keywords: E-waste, hazardous substance management (HSM), RoHS directive, labeling, supply chain management (SCM).

ENGINEERING JOURNAL Volume 20 Issue 4

Received 3 March 2016

Accepted 13 June 2016

Published 1 August 2016

Online at http://www.engj.org/

DOI:10.4186/ej.2016.20.4.1 


\section{Introduction}

Recently, many industrialized countries have strengthened aspects of their legal systems that are related with electrical and electronic equipment (EEE), especially electrical waste (E-waste). Through these regulations, industrialized countries aim to develop an E-waste management system similar to the well-known, Directive 2003/96/EC on the waste electrical and electronic equipment (hereinafter WEEE Directive ${ }^{1)}$ ) in the EU. The deep-rooted concept in the WEEE Directive is proposed in the 1989 communication document "A community strategy for waste management" (hereinafter 89 SEC,) 2). Because the waste management systems of Member States of the EU were not unified at that time, this concept was proposed in order to solve the problem was caused in immature area. The 89 SEC document indicated three problems in EC; 1 ) increasing amount of waste in community; 2) flaws in waste treatment system; and 3) discharge of hazardous waste (e.g. e-waste) outside the EC. These problems were well debated in the WEEE Directive ${ }^{3)}$ (and restriction on the use of certain hazardous substances in electrical and electronic equipment, hereinafter RoHS Directive) legislation process. RoHS and WEEE Directive were built on the same concept that Directive 1991/157/EEC on batteries and accumulators containing certain dangerous substances ${ }^{4)}$ (hereinafter Battery Directive) had set forth as a precedent, but in the final draft adopted in 20005-6), there was a division between recycling of useful materials and hazardous substance management.

Different methods were adopted in Asia. In Japan, for example, the law for promotion of utilization of recycled resources ${ }^{7)}$ was legislated in 1991. This law formulated a waste utilization and management concept. This concept was extended and led to the Home Appliances Recycling Law (HAR) ${ }^{8}$ in 1998. This law was adjusted in accordance with the RoHS Directive in 20069-10). However, prior to this adjustment the industrial sector had already thought practical RoHS Directive compliant mechanisms and/or solutions, such as quality management schemes that included probe assay and in the house environmental friendly audit standard setting.

This movement educed the needs of economical and efficient methods for a global RoHS Directive compliance scheme. In addition, the materials that were restricted in RoHS Directive has already been recognized as hazardous substances and some companies had started to ban their use voluntarily. For these reasons, the key of RoHS Directive compliance is not restriction hazardous substances but rather supply chain management $(\mathrm{SCM}){ }^{11}$. In that time, SCM was a new and immature field, so the industry was able to strive for efficiency improving. In particular, commitment document and method of marking were substituted for frequent sample analysis. Among the many economic and social transformations that occurred, the change of used materials, consideration of management techniques and streamlining of compliance proof method deserve notice. They resulted from the effort Asian manufacturers made to establish a concrete hazardous substances management. Furthermore, the meaning of labeling changed significantly according to these processes. However, it is important to point out that most of these beneficial stories have not been made available to the general public or the academic community, but rather have been kept among the related stakeholders. Many environmental regulations in EU including RoHS Directive are constructed and amended based on the scientific knowledge ${ }^{12}$ from academia and useful opinions from the stakeholder. If the communication (sharing experience) between industry and academia does not work well, the actual insistence from industrial side may not reflect to regulations easily. This could lead to undesirable results that affect all stakeholder -- including consumers -- such as paying a certain unnecessary social cost.

Given the non-public nature of the information concerning hazardous substance management and related social aspects, academic literature that comprehensively analyzes the activities of manufacture explains theirs choices is limited. In this paper, we arranged the historical information that caused among the Asian manufactures at that time from before RoHS Directive of EU. In particular, we focused on the change for labeling method about hazardous substance management, and discussed how and why the current mandatory methods have been adopted.

\section{The Difference between EU and Asia Regions - E-waste Problem Handling}

\subsection{In Case of EU}

EU was one of the first regions to identify the various problems associated with E-waste. For example, the First Environmental Action Programme ${ }^{13)}$ acknowledged the existence of waste management and anti- 
pollution problem. This earlier awareness of problems can be attributed to specific circumstance of the EU at the time, such as massive generation of hazardous and non-hazardous waste ${ }^{14}$, immature waste treatment social system, and deregulated trans-boundary movement or illegal dumping. In particular, hazardous substances dumping or exports without permission resulted in a law suit in C-304/9415).

In reaction to these problems, the European Commission had drawn up in 1998 the first draft of a directive on waste electrical and electronic equipment (WEEE), which intend to improve waste management system among Member States and to decrease hazardous substances in EEE. The first draft of WEEE Directive has a similar structure to Directive $91 / 157 / \mathrm{EC}$ on batteries, which intend to develop the management scheme for hazardous substances reduction and appropriate recycling.

Thereafter, this draft separated and was adopted as final drafts and directives in same dates and came into effect on a different day. This difference might help explain the relationship between each stakeholder involved in the matter. WEEE Directive intended to develop the E-waste management scheme at the venting phase among Member States. In general, this phase is under the responsibility of governments and manufacturers. On the other hand, RoHS Directive requires Member States to ensure the restriction on the use of the certain hazardous substances in EEE. It means that RoHS Directive requires manufacturers to not use the hazardous substances from their products.

Table 1. The scope products of RoHS Directive.

\begin{tabular}{lll}
\hline Categories of target product & RoHS1.0 target \\
\hline 1. & Large household appliances & Yes(Depends on the case) \\
\hline 2. & Small household appliances & Yes(Depends on the case) \\
3. & IT and telecommucations equipment & Yes(Depends on the case) \\
\hline 4. & Consumer equipment & Yes(Depends on the case) \\
\hline 5. & Lighting equipment & Yes(Depends on the case) \\
\hline 6. & Electrical and electronic tools \\
7. & Toys, leisure and sports equipment & Yes(Depends on the case) \\
\hline 8. & Medical devices & Yes(Depends on the case) \\
\hline 9. & Monitoring and control instruments & exemption \\
\hline 10. & Automatic dispensers & exemption \\
\hline
\end{tabular}

*Annex in RoHS Directive sets exemption for specific use of hazardous substances.

Table 2. Restricted substances.

\begin{tabular}{ll}
\hline Restricted substances & Maximum toleranted value \\
\hline Lead & $0.1 \%$ \\
\hline Mercury & $0.1 \%$ \\
Cadmium & $0.01 \%$ \\
\hline Hexavalent chromium & $0.1 \%$ \\
Polybrominated biphenyls (PBB) & $0.1 \%$ \\
\hline Polybrominated diphenyl ethers (PBDE) & $0.1 \%$ \\
\hline
\end{tabular}


However, this requirement is not easy for manufacturers to comply with because it requires a huge amount of information from their supply chain. If manufacturers fully examine one product, they need to check all of the components (E.g. iPhone5 is comprised of about 1000 parts14)). Requiring manufacturers to check them, and guaranteeing requirement compliance (see Table 1, 2 and Fig.1) in a short period of time is not feasible. At the same time, labeling requirement is only adopted in WEEE Directive, so consumers are unable to discriminate between RoHS Directive compliant and non-compliant products.

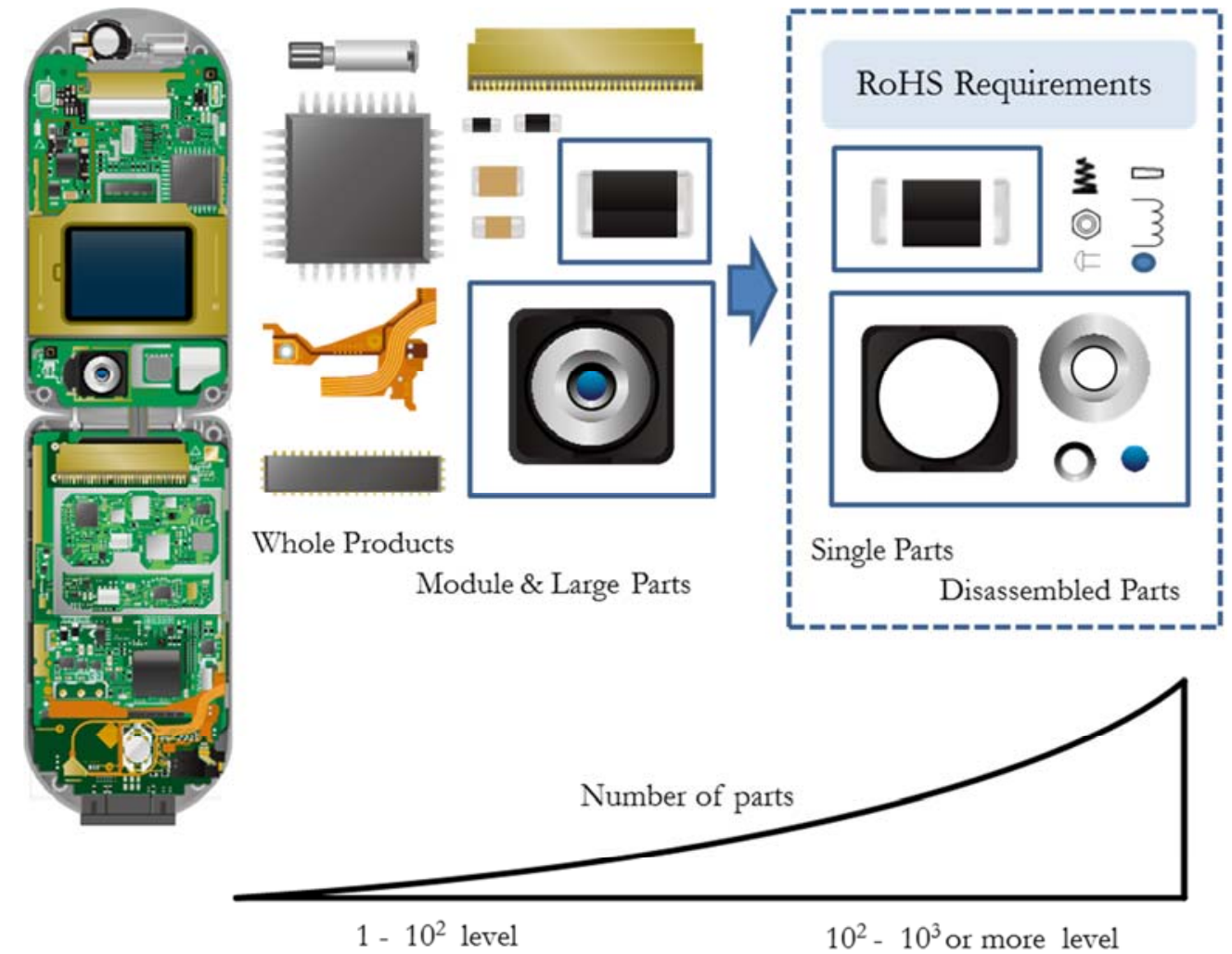

Fig. 1. RoHS Directive requires the checking of all 'Homogeneous Material'.

\subsection{In Case of Japan and Asia Region}

As we referred, promotion of utilization of secondary material is the basic concept in Japan. This tendency is as a result Japanese circumstances of disposal site. Afterward, in an effort to encourage of recycling, home appliances recycling law was enacted in 1998. This law has constructed recycling and management system for particular home appliances since 2001. Through constructing at this system, Japanese government might make it likely that manage waste and hazardous substances. In same year, the "promotion of utilization of secondary material" concept was changed to "promotion of effective utilization of resources". It set forth the goal of target expansion with same circumstances and approach ${ }^{15)}$. In 2006, this amended law added another chapter for setting J-Moss to suit RoHS Directive for hazardous substances management. This adjustment could explain Japanese system of law, especially HAR. HAR had required development of recycling scheme; therefore Japanese manufacturers attached marking for discrimination of material to improve the purity control of recycled materials. Through HAR experience, Japanese manufacturers have taken note the information propagation among industries and have been proceeded smoothly J-moss labeling methods.

Recently, regulations which aim to construct E-waste treatment are also enacted in other Asian region ${ }^{16-}$ 17). Explanations of the reason why the incentive of legislation and enforcement power are depend on their own circumstances. However, in the case of hazardous substances, many Asian countries adopt a labeling requirement alike J-moss. Adaptation a labeling requirement in Asia can be potentially explained by region characteristics. Nowadays, Asian region serve as a huge factory of various products. From that aspect alone, Asian region has reason to welcome "practical" methods. 


\section{The Expansion of Hazardous Substances Management - in EU and Asia Region}

The RoHS Directive isn't the fastest regulation which restricts substances in specific product. In fact, EU had enacted another directive in 1991, which restricts substances in battery (Battery Directive). In the same way, it enacted yet another directive in 2000 for end-of-life vehicles ${ }^{18)}$. RoHS Directive can be argued as the existing system expansion for E-waste. RoHS Directive intend to restriction specific substances and decreasing hazardousness of EEE. The background of this regulation not just improves environmental suitability and recycling rate, but EU circumstances. EU is the biggest market and importer of EEE products. Of course, various manufactures of EEE were located in EU Member States. However, respectable Asian region producers likely need through manufacturing. RoHS Directive is effective for non EU producers to become more aware of environmentally friendly manufacturing.

Table 3. Unit number of HS85 items of EU external trade.

\begin{tabular}{|c|c|c|c|c|c|}
\hline & 2010 & 2011 & 2012 & 2013 & 2014 \\
\hline China & $7,011,200,380$ & $7,240,217,794$ & $7,033,000,877$ & $7,236,439,558$ & $7,665,265,756$ \\
\hline Japan & $794,815,249$ & $741,913,628$ & $625,335,470$ & $568,459,986$ & $539,339,484$ \\
\hline U.S. & $608,026,328$ & $802,038,052$ & $1,003,712,255$ & $915,577,176$ & $681,758,599$ \\
\hline Swizerland & $649,597,559$ & $539,840,693$ & $277,013,333$ & $261,211,690$ & $264,210,870$ \\
\hline South Korea & $637,817,039$ & $448,204,509$ & $327,105,245$ & $293,511,148$ & $296,266,275$ \\
\hline Singapore & $169,310,504$ & $300,619,620$ & $530,120,108$ & $549,916,117$ & $452,548,784$ \\
\hline Malaysia & $198,238,880$ & $180,452,712$ & $161,453,244$ & $184,557,560$ & $195,466,297$ \\
\hline Hong Kong & $340,010,040$ & $292,553,962$ & $317,988,285$ & $348,228,729$ & $475,755,804$ \\
\hline Taiwan & $853,528,226$ & $579,086,261$ & $670,186,585$ & $824,948,584$ & $645,850,896$ \\
\hline Indonesia & $370,914,928$ & $270,769,009$ & $210,992,539$ & $347,276,060$ & $331,856,459$ \\
\hline Thailand & $452,481,728$ & $497,657,900$ & $429,484,140$ & $429,880,621$ & $580,407,638$ \\
\hline Philippines & $131,115,692$ & $52,587,439$ & $74,871,126$ & $72,697,151$ & $46,876,531$ \\
\hline India & $593,345,863$ & $674,477,953$ & $1,036,557,945$ & $515,673,947$ & $434,919,890$ \\
\hline
\end{tabular}

Source: World Trade Atlas

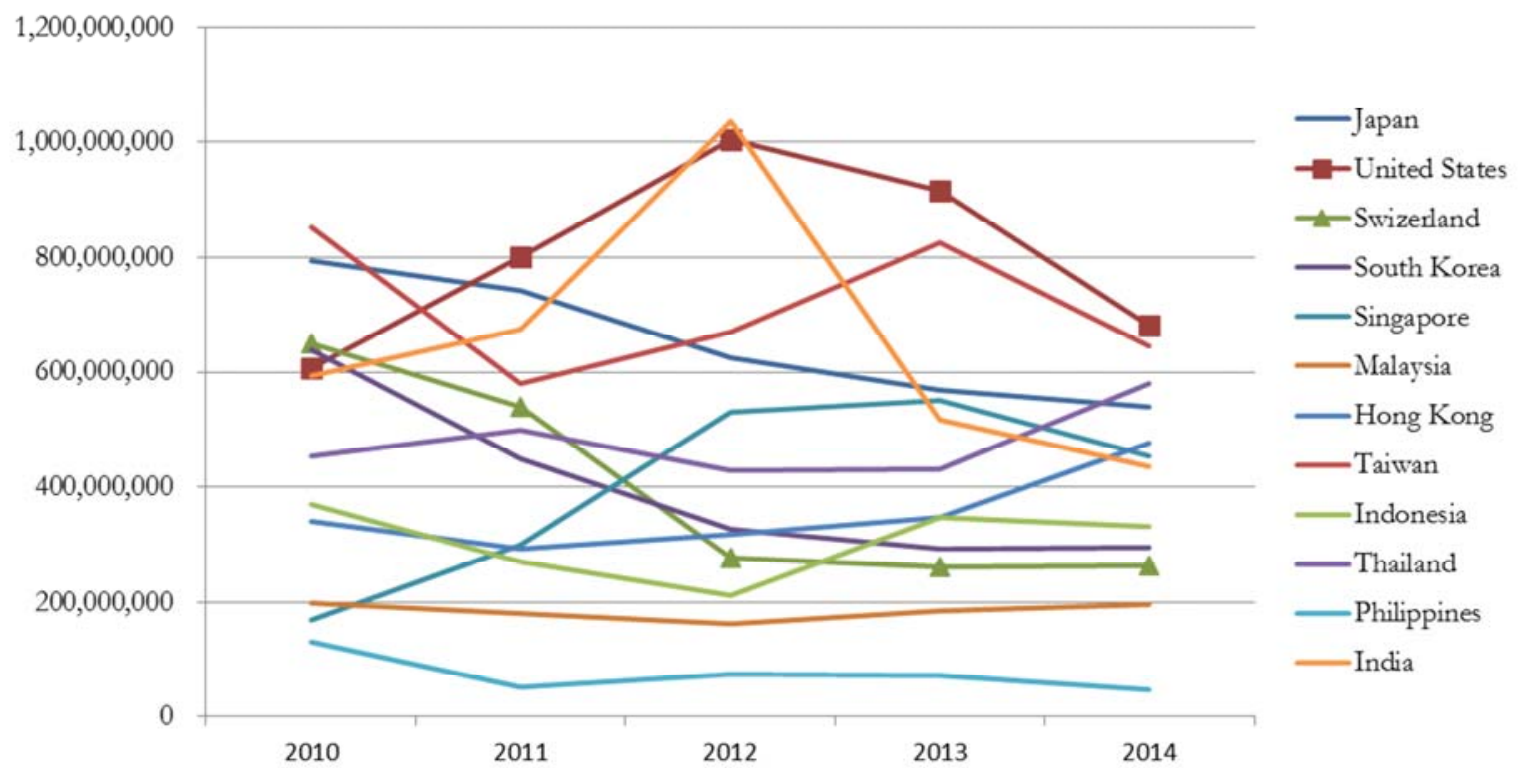

Fig. 2. EU import volume of commodity (China excluded).

Source: World Trade Atlas 
"Effective" RoHS Directive also requires Member State's authorities to enforce it properly. However, there were no clues for enforcement, and most of authorities have limitations in cost and effort. Hence, the methods of enforcement are such as custom check and/or unannounced inspection were adopted.

On the other hand, Asian region governments didn't adopt EU enforcement methods. It could be argued that in Asian region (especially in Japan), government and manufacturers might have consciousness of "customers" but "producers". Actually, we can find the world's leading exporters of EU among Asian regions (see Table3). Table3 show the top 13 exporting countries to EU among 2010 to 2014. We can find China exports huge amount (China exporting amount is about ten times as large as other countries) of electrical Machinery and Equipment and Parts (which fall into a HS category 85; in what follows commodity: 85). And Fig.2 shows the major exporter countries except China. We also can be confirmed United States and Switzerland are decreased, and Asian countries are increased. This tendency could be explained RoHS Directive compliance.

It is commonly known as EU trading character, Member States of EU do a lot of trade among inter EU. However, huge amounts of commodity: 85 were imported from Asian countries. An already-known fact, there are so many electrical and electronic manufacturers sited East Asian region, especially electrical parts manufacturers.

In additionally, as we referred, electrical and electronic equipment is assembled by a considerable number of parts. This electronic manufacturer's supply chain structure raises the RoHS requirement spreading and they need to make sure what manufacturer made and what kinds of substances used for part. However, most of Asian manufacturers are engaged part manufacturing and required RoHS implementation by customer's requirement. Since, RoHS Directive requirements become overloaded with Asian manufacturers for prove assay. You could find the definition referred in amended RoHS Directive (Directive 2011/65/EU ${ }^{19)}$ hereinafter RoHS2.0) definition in article 3(20) as following; 'bomogeneous material' means one material of uniform composition throughout or a material, consisting of a combination of materials, that cannot be disjointed or separated into different materials by mechanical actions such as unscrewing, cutting, crushing, grinding and abrasive processes'.

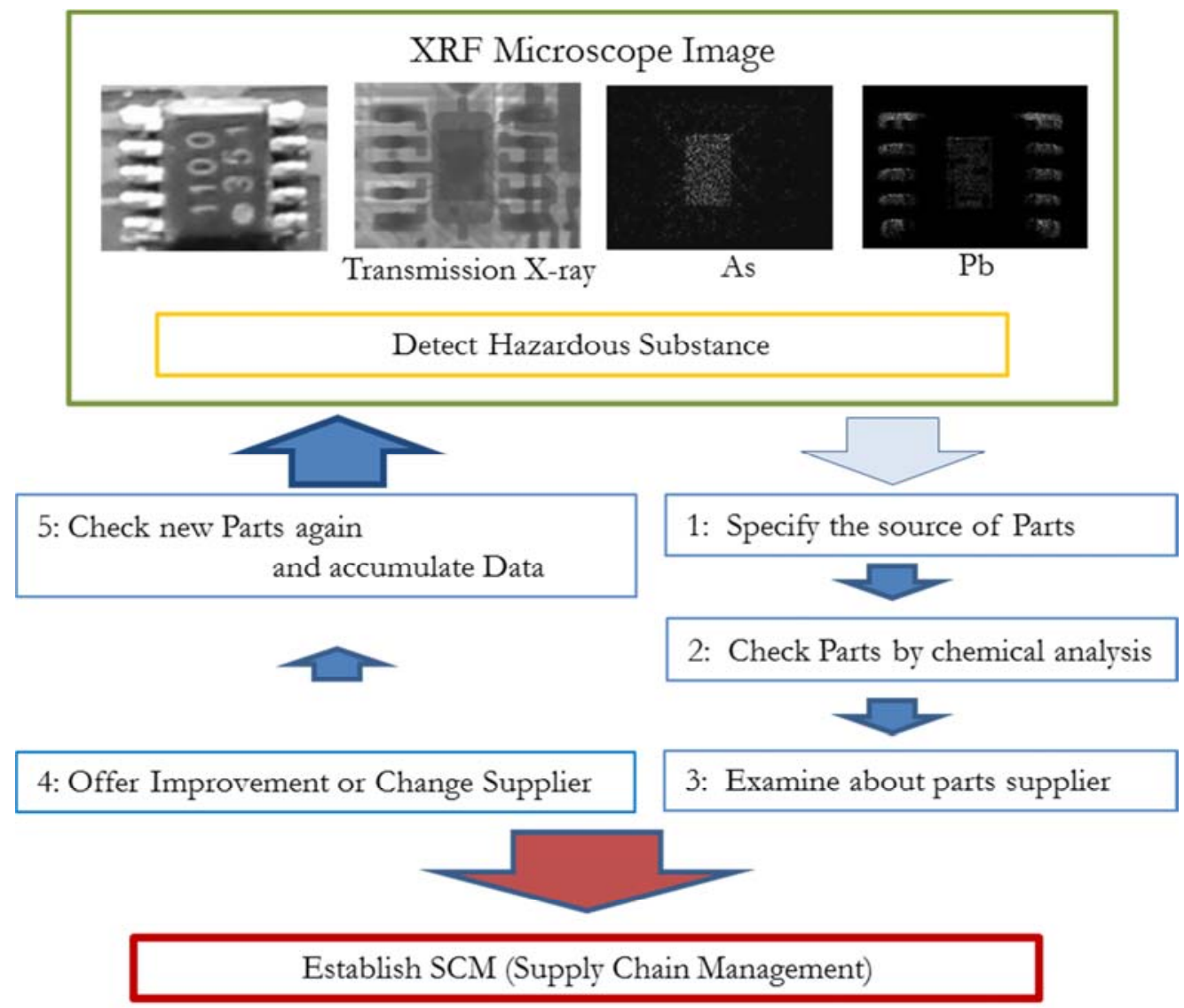

Fig. 3. Regular checking work have led to establish SCM. 
This article is taken in context from RoHS Directive FAQ ${ }^{20)}$, not means one part needs only one analysis. For example, if one part is composed by 10 materials, it needs the analyzed data of 10 materials for proving the compliance with RoHS Directive requirement. As seen from the above, definition of 'homogeneous material' recognize in directive from RoHS2.0. Therefore, manufacturers had no way of telling proved of compliance in 2003. Since then, they developed and utilize the portable X-ray analytical equipment or elemental mapping analysis instruments such as XRF micro scope and establish their own supply chain management (see Fig.3).

In addition, manufacturers also had sought every possible way to make sure the restricted in RoHS Directive substances elimination. In the point of view about hazardous substances, even if it was possible to develop lead free solder, engineers have been predicting many obstacles to be tackled ${ }^{22}$. From the earlier research stage, it was apparent that there are much difference between lead solder and lead free solder, such as melting temperature and wettability. They had been recognized the necessity to change the production line for the correspondence to the troubles caused by these differences of feature, for instance the damage of devices and drop of yield etc. In the result of research and development among manufacturers through supply chain in the periods 2002 to 2005, they found substitution of lead solder. Hence, nowadays, substituted lead solder is turned into actual utilization among the world manufacturers. The how and why of these substitutions, research and development, and Asian manufacturers' contribution is a little known fact.

As can see in Table4, RoHS Directive had become effective in 2006; however, there is no guideline compliance. This absence means no manufacturers have sample answers for RoHS compliance, and manufacturers had to seek methods to make sure their compliance. There were the horrible risks; hence, Japanese manufacturer had adopted extremely strict methods to make sure their compliance. Due to make sure comply with "customer requirement" and "risk avoidance", they had done the maximum possible such as probe assay for all of parts. Since, as we referred, to make sure the compliance for RoHS requirement, they need to proof the all of minimum unit part and materials such as paste or glue through the all of supply chain. (Furthermore, the minimum unit part or material manufacturers might be not to understand RoHS requirement.)

However, after the confusion among the producers, they look for more practical methods which consist with economic efficiency and safeness, especially from 2006. As the result, manufacturers keep tabs on their products by production lot, and certify them with plain analysis methods. Various manufacturers adopted their own RoHS compliance proving system and adjust it through supply chain negotiation. After that, they adopt marking methods for self-declaration of conformity with RoHS Directive.

Table 4. Condensed chronology of regulation and labelling.

\begin{tabular}{|c|c|c|c|c|c|c|c|c|c|c|c|c|c|c|c|}
\hline \multicolumn{2}{|c|}{ Reguration } & & & & & & & & & & & & & . & \\
\hline & & 1991 & $\sim$ & 1998 & $\sim$ & 2000 & 2001 & $\sim$ & 2003 & $\sim$ & 2005 & 2006 & 2007 & 2009 & 2013 \\
\hline \multirow{2}{*}{$\mathrm{EU}$} & RoHS & & & 1st draft & & $\begin{array}{l}\text { Final } \\
\text { Draft }\end{array}$ & & & Published & & & In Effect & & & (RoHS2) \\
\hline & WEEE & & & & & $\begin{array}{l}\text { Final } \\
\text { Draft }\end{array}$ & & & & & In Effect & & & & \\
\hline Japan & HAR* $^{*}$ & Concept & & Adopt & & & In Effect & & & & & & & & \\
\hline \multicolumn{2}{|c|}{ Labeling } & & & & & & & & & & & & & & \\
\hline Japan & J-Moss & & & & & & & & & & & Added & & & \\
\hline Thai & TIS** & & & & & & & & & & & & $\begin{array}{l}\text { Circular } \\
\text { Notice }\end{array}$ & In effect & \\
\hline China & C-RoHS & & & & & & & & & & & Adopt & & & \\
\hline
\end{tabular}

※Other RoHS regulations in Asian regions are in effect after 2011.

*HAR: Home Appliances Recycling Law $\quad$ ** TIS: Thai Industrial Standard (2368-2511)

Which means that producers who in middle or upper stream of supply chain have to comply with downstream "customer" requirement. Needless to say of their effort for comply with the "customer" requirement. However, comply with all individual requirements is not feasible. As the result, they prepared the minimum of required information to decrease their clerical work. As we have already mentioned, 
RoHS2.0 adopted "practical" methods in CE marking system. These restrictions of the use of hazardous substances movement are common in Asia region. Although, they can divide two movements, one is legal binding and another is industry-led. The latter affects RoHS Directive because of it is more practicable method and suitable for producers and governments. It is possible to say that Asian compliance methods enough practicable in EU.

Figure 4 provides the following example of RoHS relating labeling, they show content and/or attention. RoHS labeling on product means "this product satisfies the RoHS requirement", and CE labeling means satisfy product standards -include RoHS requirement- among EU since 2013. Nowadays, labeling method is widespread application of product information, and used as substitution methods of probe assay.

This substitution method has expanded especially among Asian region such as J-Moss (Japan- the Marking for presence of the specific chemical substances for electrical and electronic equipment) in Japan and TIS (Thai Industrial Standard) 2368-2551 (similar with IEC 62321) in Thailand. Asian tendency has an impact among EU region. In fact, amended RoHS Directive (RoHS2.0; Directive 2011/65/EU) adopted $\mathrm{CE}$ marking requirement. This marking requirement commands for producers to show RoHS compliance as mandatory information.

Although such labeling method for RoHS compliance, it is not completed from point of view of generalization in some countries. For revolving this problems, some manufacturer started to declare the "RoHS conformity of own products" on the website in each country ${ }^{23}$. It is considered a certain process of time for spreading of labeling method.

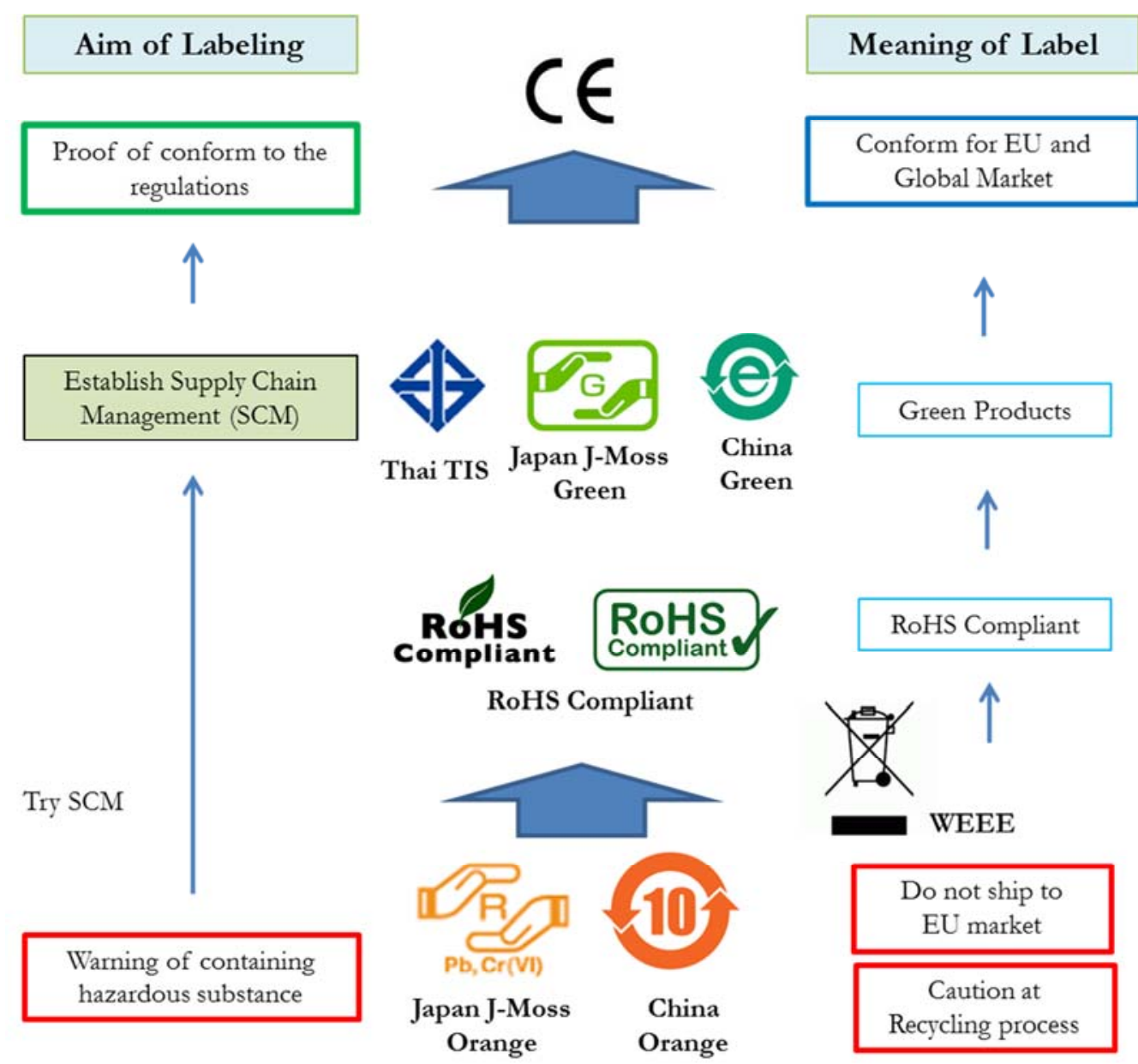

*.. J-Moss Orange mark means Hazardous substances contain (this picture show $\mathrm{Pb}$ and $\mathrm{Cr}$ (vi) containing) **.. China RoHS marking means Hazardous substances contain (however, no other information is shown)

Fig. 4. Changing aim and meaning of label related RoHS. 
In addition the supply chain management related to hazardous substances (SCM) is also evolving. Now it is possible to confirm easily the compliance with the website of the manufacturers. In such a page, it is possible to confirm compliance by searching from the Product Part Number and, of product Categories24). Also, BOM Check (Bill of materials) is often used tool of SCM25). This is a chemical substance management tools that are built with suppliers and manufacturers (database). RoHS2.0 In Until now, devices were excluded (medical equipment, etc.) has been targeted, and is used to check for performing CE marking such devices.

\section{Conclusion}

HSM in EEE has been conducted in various methods since middle of 1990s. In this paper, regarding to a method of HSM, we organized historically correspondence of manufacturing factories of electronic products in Asian countries. And we clarified that the meaning of the labeling to the product was gradually shifting along with development stage of HSM.

Eventually, labeling as a means of communication tools in the HSM was changed from "Warning of containing hazardous substance" to "Proof of conforms to the regulations". Also, the method for getting of certification became from "Submit analyzing data" to "Establish the SCM". As we have described, quality management methods with labeling based on SMC are superior in efficiency, effectiveness and comprehensible. This advantage is desirable under the complicated chemical regulation circumstances not only SMC but also information presentation for consumers.

In this paper, Asian RoHS compliance methods and its spreading have been discussed. It shown one example that certain system for complying with a regulation contributed to streamlining for other regulations. From another aspect, a knowledge expansion alike this way can advance a level of chemical regulation compliance and regulation itself. Labeling and SCM have been evolved in Asian region. Consequently, producers in Asia region were considered desirable to encourage their interest among unfamiliar countries regulations. Their implication was mainly considered to be due to differences in industrial structures between Asia and EU.

In this case, we have shown the importance of contributing a regulation making side and actual manufacture industry for to establish effective system. Knowledge and experience from RoHS Directive will be important in considering the future institutional social system such as E-Waste recycling scheme design in Asian region and circular economy (CE) policy in EU.

\section{References}

[1] European Parliament and of the Council. (2003). Directive 2002/96/EC on waste electrical and electronic equipment (WEEE) [PDF]. Available: http://eur-lex.europa.eu/legalcontent/EN/TXT/PDF/?uri=CELEX:32002L0096\&from=EN

[2] Commission of the European Community. (1989). Communication from the commission to the council and to parliament [PDF]. Available http://aei.pitt.edu/5679/1/5679.pdf

[3] European Parliament and of the Council. (2003). Directive 2002/95/EC on the restriction of the use of certain hazardous substances in electrical and electronic equipment [PDF]. Available: http://eur-lex.europa.eu/legalcontent/EN/TXT/PDF/?uri=CELEX:32002L0095\&from=EN

[4] European Council. (1991). Directive 91/157/EEC on batteries and accumulators containing certain dangerous substances $\quad$ PvDF]. Available: http://eur-lex.europa.eu/legalcontent/EN/TXT/PDF/?uri=CELEX:31991L0157\&from $=$ EN

[5] European Commission. (2000). Proposal for a Directive of the European Parliament and of the Council on waste electrical and electronic equipment [PDF]. Available: http://eur-lex.europa.eu/legalcontent/EN/TXT/PDF/?uri=CELEX:52000PC0347(01)\&from=EN

[6] European Commission. (2000). Proposal for a Directive of the European Parliament and of the Council on the restriction of the use of certain hazardous substances in electrical and electronic equipment [PDF]. Available: http://eur-lex.europa.eu/legal-content/EN/TXT/PDF/?uri=CELEX:52000PC0347(02)\&from=EN

[7] Ministry of Economy, Trade and Industry. (1991). Saisei shigen-no riyou-no sokushin-ni kansuru bouritu-no itibu-wo kaiseisuru bouritsu sin-kyun taishoubyou (in Japanese) [PDF]. Available: http://www.meti.go.jp/policy/recycle/main/admin_info/law/02/pdf/houreishinkyu.pdf 
[8] Ministry of Economy, Trade and Industry. (1998). Home Appliance Recycling Law [PDF]. Available: http://www.meti.go.jp/policy/it_policy/kaden_recycle/en_cha/pdf/english.pdf

[9] Ministry of Economy, Trade and Industry. (2006). Shigen-no yunkou-na riyou-no sokusbin-ni kansuru bouritussikourei-no ishibu-wo kaiseisuru seirei sin-kyun taishoubyou (in Japanese) [PDF]. Available: http://www.meti.go.jp/policy/recycle/main/3r_policy/policy/pdf/j-moss_1.pdf

[10] JIS C 0950:2008. "The marking for presence of the specific chemical substances for electrical and electronic equipment" (in Japanese) [PDF]. Available http://www.jisc.go.jp/app/pager?id=1517324

[11] Collegium of RoHS (ED.), "101 of RoHS directive (in Japanese)," in Q\&A de-yokuwakaru kokogashiritai sekai no RoHS hou(in Japanese), 1st ed. Tokyo, Japan, 2011, ch. 1, pp. 10-42.

[12] Reference [3], preamble (7), (8), (10), (11), Articles 4, 5, and 6.

[13] Council of the European Communities and of the representatives of the governments of the member states meeting in the council. (1973). The programme of Action of the European Communities on the environment [PDF]. Available: http://eur-lex.europa.eu/legalcontent/EN/TXT/PDF/?uri=CELEX:41973X1220\&from=EN

[14] European commission DG environment. (1998). Proposal for a Directive on waste from electrical and electronic equipment (in Archive).

[15] Judgement of the Court. (1997). Criminal proceedings against Euro Tombesi and Adino Tombesi (C304/94), Roberto Santella (C-330/94), Giovanni Muzi and others (C-342/94) and Anselmo Savini (C224/95) [PDF]. Available: http://curia.europa.eu/juris/showPdf.jsf;jsessionid=9ea7d2dc30db76cf8ec1625e41a3a117a53cee0318 8c.e34KaxiLc3qMb40Rch0SaxuLaxr0?text=\&docid=100122\&pageIndex=0\&doclang=EN\&mode=ls $\mathrm{t} \& \mathrm{dir}=\& \mathrm{occ}=$ first\&part $=1 \& \mathrm{cid}=1448852$

[16] Minatake Kashio, iPhone-no sugoi nakami te-no naka-ni birogaru saisentan gijutu-no sekai, $1^{\text {st }}$ ed. Tokyo, Japan: Nihon Jitsugyou sha, (2010).

[17] Ministry of Economy, Trade and Industry and Ministry of Environment. (1998). Act on the Promotion of Effective Utilization of Resources [online]. Available: http:/ /www.japaneselawtranslation.go.jp/law/detail/?id $=80 \& v m=04 \& \mathrm{re}=01$

[18] Ministry of environment and forests. (2011). e-waste (Management and Handling) Rules, 2010 [PDF]. Available: http://www.moef.nic.in/downloads/rules-and-regulations/1035e_eng.pdf

[19] European Council. (2000). Directive 2000/53/EC on end-of-life vehicles [PDF]. Available: http://eurlex.europa.eu/legal-content/EN/TXT/PDF/?uri=CELEX:32000L0053\&from=EN

[20] European Parliament and of the Council. (2011). Directive 2011/65/EU on the restriction of the use of certain hazardous substances in electrical and electronic equipment [PDF]. Available: http://eurlex.europa.eu/legal-content/EN/TXT/PDF/?uri=CELEX:32011L0065\&from=EN

[21] European Commission Directorate-General Environment. (2006). Frequently Asked Questions on Directive 2002/95/EC on the Restriction of the Use of certain Hazardous Substances in Electrical and Electronic Equipment (RoHS) and Directive 2002/96/EC on Waste Electrical and electronic Equipment (WEEE) (Archive) [PDF]. Available: http://www.grsbatterien.de/fileadmin/user_upload/Download/Hersteller/FAQonRoHS.pdf

[22] Japan Electronics and Information Technology Industries Association, "JEITA Namari free-ka kansui kinkyuu teigen houkokusho," JEITA, Tokyo, Japan. March, 2005.

[23] Takahiro Soma. "Asia-no Kagaku-busshitsu Kisei (in Japanese)," Nikkei Ecology, No.172, pp.35 October, 2013

[24] Panasonic Co., Ltd.. (2015). Environment \& Regulations [online] Available: http://na.industrial.panasonic.com/environment-regulations

[25] TDK Co., Ltd.. (2015). Environment [online] Available: http://product.tdk.com/info/en/environment/index.html

[26] BOM check.net. (2015). Substances Declarations and Conflict Minerals Web Database [online] Available: https://www.bomcheck.net/en/ 